\title{
ENTREPRENEURSHIP AS AN AGENT FOR SOCIAL-ETHICAL REFORM: AN ISLAMIC PERSPECTIVE
}

\author{
Amana Raquib* \\ Imran Khan**
}

\begin{abstract}
This paper argues that various contemporary crises are both the cause and effect of contemporary consumer culture, which tends to create artificial needs by marketing unneeded products and services as elements of identity and self-image. Thus, Muslim intellectuals and entrepreneurs need to join hands towards the holistic design of an Islamic business ethics. However, the way Muslim entrepreneurs learn and teach business currently does not encourage a sense of responsibility towards finding solutions. Many Muslim entrepreneurs are unaware either of the extent, nature or magnitude of the crises resulting from overconsumption, or of Islam's religio-ethicospiritual perspective and guidance on this matter. Thus, presently Muslim-run businesses constitute part of the problem rather than the solution. To act as agents for reform, Muslim entrepreneurs require a deeper understanding of the rich repository of Islamic beliefs, concepts and practices that need to be revived within societies through their business models and practices.
\end{abstract}

Keywords: Religio-ethical holism, Postmodern Consumer Culture, Overconsumption, Islamic Business Model, Social Reform, Change Agents, Tazkiya, Halal Industry

\section{Introduction}

When it comes to thinking about how a business needs to be run on Islamic principles or what should be the attributes of a Muslim entrepreneur, the concepts we generally come across are the ones having to do with the prohibition of interest, staying away from cheating or fraud and dishonesty and dealing fairly with everyone at all levels, including amongst employees and customers. ${ }^{1}$ The businessman/woman or entrepreneur up until recently had been considered to earn halal (permissible) profit for himself/herself and not indulge in haram (prohibited) products, services and transactions, both material and financial. At most, a few writings talk about the CSR (corporate social responsibility) dimension and hence asked Muslim run businesses to donate to charitable community causes, such as schools and hospitals, or else take initiative and build 
their own public welfare institutions. This has narrowed down the scope and responsibility of a Muslim entrepreneur to a great extent. Apart from the fact that even from the traditional Islamic vantage point of tijarah (trade), this brief list of ethical expectations from Muslim business owners is insufficient, in the contemporary postmodern, postindustrial context it needs critical revision and the addition of some very important ethical ingredients. Although some recent research on Islamically guided economics and environmentalism have argued that Muslim businesses should be more ethically aware and responsible ${ }^{2}$ for the sake of sustainability and human well-being, we do not see a fuller critical analysis of the philosophy of business that underlies our contemporary postmodern culture and the development of an alternative philosophy that should then inform the ethical contours of Muslim businesses. ${ }^{3}$

It is the need of the time that Muslim intellectuals and entrepreneurs join hands in a holistic appraisal and design an Islamic business ethics/Islamic business model for our contemporary late modern/postmodern consumer culture. The prevalent consumer culture tends to create artificial needs by marketing unneeded products and services as elements of identity and self-image. This paper argues that contemporary social, cultural, economic, political, psychologicalspiritual-existential and environmental crises are both the cause and effect of contemporary consumer culture. Muslim societies constitute a large chunk of the wasteful consumerism practiced at the global level. This situation places immense responsibility on Muslim businesses and entrepreneurs. However, the way Muslim entrepreneurs learn and teach business currently does not encourage assuming that responsibility. Many Muslim entrepreneurs are unaware of the extent, nature and magnitude of the crises resulting from unthinking overconsumption. Even the few who understand the pitfalls of consumer culture are nevertheless not aware of the Islamic religio-ethico-spiritual perspective and the guidance it provides in this respect. In their present shape and form, Muslim run businesses constitute part of the problem, rather than offer holistic solutions. To act as agents for social-ethical-spiritual reform, both experienced and budding Muslim entrepreneurs require a deeper understanding of the rich repository of Islamic beliefs, concepts and practices that need to be revived within societies through their business models and practices.

\section{Revisiting Progress and Development}

Following the deepening of human crises on all levels, such as the psychospiritual, social, economic and financial, political and environmental, a number of intellectuals, academics and social scientists have attributed these crises to the 
one dimensional nature of progress and development. A growing literature is now available on the ideas of genuine progress, genuine happiness and genuine wealth. In places as far away and culturally distinct as Canada and Bhutan, measures such as the Genuine Happiness Indicator (GHI) and Genuine Progress Indicator (GPI) have questioned the more money-based metrics of gauging economic performance, such as GDP, stock market indices, consumer spending and so on. ${ }^{4}$ Genuine wealth is understood in these paradigms as "conditions of well-being that are true to our core values of life". ${ }^{5}$ Competition, according to this view, is not necessarily seen as antithetical to cooperation but more as a communal striving toward a common goal. The crux of these works is the acknowledgment of the fact that increasing economic growth does not necessarily improve human well-being and happiness. Well-being is understood in terms of living a fulfilling and meaningful life that contributes positively to the community and society, taking into consideration values that lie outside the realm of monetary exchange and that are often in inverse correlation to GDP.

GPI, for instance, adjusts personal consumption expenditures by subtracting the value of lost leisure time, family breakdown, commuting time and so forth, ${ }^{6}$ hence conceiving societal progress and human development along different lines. Amongst the 51 indicators of sustainable well-being in Alberta, Canada, are youth suicide rate, long term environmental damage, quality of air, water quality, parks and wilderness, obesity, leisure time, volunteerism, parenting and eldercare, family breakdown measured through the divorce rate, savings as against consumer expenditure, and self-reported happiness of the individualsfactors that we do not find in the more mainstream appraisals of a society's economic growth. The earlier model of progress driven by consumption and productivity, hoarding and profit maximisation, is replaced in this holistic model with the pursuit of happiness, genuine well-being, sharing, gifting, sustainability and reciprocity. In this model, well-being and human development is not disconnected from virtue. GPI also distinguishes between fundamental life needs and wants, and also between the means of well-being and their ultimate ends. Health, wealth, mobility, knowledge, communication and consumer goods are treated as intermediate ends that have the potential to contribute to the ultimate ends, such as happiness, harmony, fulfillment, self-respect, self-realisation, community, enlightenment and seeking God. Purposefulness and meaning of life play a central role in the assessment of a good life. Trust and belongingness, community vitality and sustainable food production are to be given as important a place as living standards and affordable housing.

Some Muslim scholars and economists, such as Nasr, Setia, and Raquib (2015), ${ }^{7}$ have proposed a Muslim understanding of holistic happiness along similar lines. An alternative paradigm has also been developed by proponents of 
Human Development, such as Mahbub ul Haq and Amartya Sen, who advocate shifting the focus of economics from accumulation of wealth to the idea that "humans are both the means and the end of economic development." and other works highlight the problematic nature of current models of human development whereby happiness is seen and measured as reducing the number of unfulfilled needs.

\section{Entrepreneurship from an Islamic Perspective (EIP)}

It is worthwhile noting that in contemporary scholarship on Entrepreneurship from an Islamic Perspective (EIP), the role of materialism has been discussed as an integral part of understanding social and business activities. Egyptian Muslims, for instance, were found to view money and financial issues as a matter of community concern. Unlike materialist and individualist societies which emphasise self-maximising behaviour, and where material possession is considered more important than community good, Islamic or Muslim cultures emphasise less on possessing material goods than on altruism, cultivation of virtue and social goods. All of this suggests that entrepreneurship in Islamic societies should be representative of this Muslim sensibility and must operate differently from consumerist societies. However, if this is the case, why then do we see entrepreneurs from consumer cultures taking the lead in designing environment friendly, ethical businesses that shun extravagance and promote the consumption of used and recycled items, thereby pulling individuals out of the vicious cycle of overconsumption leading to excessive waste? Overconsumption of goods and services interferes with praiseworthy human character traits, instead reinforcing blameworthy traits such as hasad (envy), hirs (greed) and riya (ostentatiousness). Not only are Muslim entrepreneurs not taking the lead, they seem to be totally absent from the picture. ${ }^{9}$

This is especially surprising in the light of Islamic ethical philosophy, which is meant to create a balanced world with balanced individuals as both entrepreneurs and consumers. EIP is currently defined as the "discovery, evaluation and exploitation of opportunities utilising an Islamic belief system in the business environment". ${ }^{10}$ According to this broad definition, since Islam, as a religion, gives importance to business activities that improve society in a holistic manner, when Muslims engage in entrepreneurial activities, it is assumed that they would consider them a business obligation and hence Islamic teachings, values and ideas, guided by the ethical-spiritual guidelines of the shariah, would shape their economic/entrepreneurial activities, both in their aims and methods. The Qur'an (3:110) says, "you order for right, true and welfare oriented activities and keep 
the people away from sin and undesirable tasks". This call to social justice is also reflected in the morality of Muslim entrepreneurs who respect their religious faith but at the same time are business people. Accordingly, the combination of various ethical, social, environmental and economic factors that are in agreement with the shariah form the basis of the achievements of business in Islam.

An example would serve the purpose. When it comes to the clothing and textile industry, the Western world is putting up ideas like Clothes' Swapping, Closed Loop Production and Zero Waste. H\&M has taken the lead in research on creating recycled clothes using partly recycled and partly virgin (unused) material to create fabric. ${ }^{11}$ New technologies are being explored to create recycled fabrics that are durable, of higher quality and that do not go to waste quickly. Although this search for new technologies is taking place, there is also a sense of finding ways to persuade people to use their clothes for the longest period of time. The following is representative of that:

Why are we hung up on recycling? Shouldn't we just wear our clothes for longer? Yes, this is crucial and some brands have launched initiatives to encourage it. Lynn Wilson, textiles expert and manager of the Love your Clothes, offers Howies as an example, which is adding emotional value to clothing and encouraging consumers to pass on robust garments and tell their story.... While you should extend life first, there should always be a route to recycling eventually, says Goldsworthy. "The trouble is that we think of materials in a 'human timeframe', when actually they can relate to materials which in some cases took millions of years to form (and will take 100's of years to decompose). We need some longer-term thinking." 12

Problems with closed loop textiles include low quality, hence a need to have few high quality items and not fast fashion. ${ }^{13}$ In the Pakistani context, khazanay. $\mathrm{pk}^{14}$ is one such initiative which deals only in used products. Khazanay is the world's first online store which sells second hand, original branded sneakers and shirts. While the website proudly presents the originality of the products, the ethical reasons for working with used products is nowhere mentioned.

Having come across the Muslim imperative in the definition of EIP, it seems quite surprising that cultures deemed to be materialist, individualist and consumerist in the literature on EIP are taking exemplary initiatives to curb excessive consumption of unnecessary clothes, whereas Muslim entrepreneurs who have a rich repository of religious, ethical and spiritual ideas, concepts, practices and a long history of people practicing the trait of $z u h d$, are not putting that into practice. Zuhd means "self-restraint and self-discipline or reducing worldly pleasures and resisting human desires (shahwah), except those which satisfy genuine needs, for 
the sake of eternal happiness in the Hereafter". ${ }^{15}$ From the point of view of Islamic epistemology and ethics, using products such as clothes, shoes, handbags and purses, for longer periods of time, swapping them within the community and recycling are far more viable and in line with the Islamic temperament of zuhd and qana'ah (frugal contentment) as a means of fulfilling the goals of maslaha (societal well-being) and khilafa (trusteeship) while treating the resources of earth as amanah (trust). It is mentioned in the Qur'an:

And (remember) when your Lord said to the angels: "Verily, I am going to place a steward (khalifa) on earth." They said: "Will You place therein those who will make mischief therein and shed blood, - while we glorify You with praises and thanks and sanctify You." He (Allah) said: "I know that which you do not know." (Quran 2:30).

The idea of tazkiya (inner self purification) is more likely to convince Muslims to adopt the above mentioned way of life than environmentalism and going green. Instead of spending energy, resources and time a developing technologies for the creation of new super fabrics, it is the responsibility of Muslim entrepreneurs to develop and design business models that incorporate tazkiya, which enjoins consumers to buy less, shop less and reuse more. This responsibility to implement maslaha falls on today's postmodern consumer culture, especially on Muslim entrepreneurs, since social-cultural-psychological-political realities are being created and dismantled through businesses and products. Hoque et al. states that "many Muslims still pay no or little attention to the Islamic guide lines while developing and managing business enterprises". ${ }^{16}$ The question arises as to whether this is due to a lack of guidance in Islam about how to conduct entrepreneurship in an ethical-religious manner or if it is a result of a lack of awareness amongst Muslim entrepreneurs about that guidance. The genre of EIP convinces us that the former is not the case.

The core motivating factor for Muslim entrepreneurs should be combining religious beliefs such as social responsibility with business ideas. ${ }^{17}$ The acquisition of contextually beneficial knowledge is crucial for Muslims to practice their faith. Therefore, in the light of various contemporary crises, teaching Islamic businesses about the treasures of Islamic spirituality and epistemology, in addition to contemporary knowledge on environmentally friendly practices, should be made a priority towards authentic EIP. Muslim entrepreneurs need to be aware of how innovation is changing and affecting consumer demand. They should be aware of environmental demands and how new manifestations of environmental, psychological and social degradation are taking place. As new innovations come into the marketplace it is essential for Muslim entrepreneurs to think about how they will affect not only existing business structures, but also psycho-spiritual 
and intellectual-cultural realities. ${ }^{18}$

Few scholars have discussed what is required to develop Muslim entrepreneurs. Practical training and awareness creation (Hoque et al. 2014) have been brought up as among the most important ingredients. Another important aspect proposed by Chowdhury is that both inputs and goals should involve religious ideas and work in unison with the policymakers to link business interests to a holistic understanding of religion. ${ }^{19}$ This could potentially increase the number of entrepreneurs conducting business from an Islamic perspective. Islamic ideas, thought, moral-spiritual values and ethics should inform the business model and goals such as survival, prosperity, peace, harmony and growth need to be interpreted from the holistic Islamic idea of falah (holistic success). ${ }^{20}$ The new genre of EIP informs us that "when looking at the organisation as a profitable entity from the Islamic perspective, it is not expected to be only profitable but also it is expected to be in alignment with worldly socio-economic welfare as well as spiritual growth". Unlike any other entrepreneur who will judge success in financial returns, from the Islamic perspective, "entrepreneurial success is measured not only by personal financial gains but also how well religious goals are achieved which can provide the entrepreneur with rewards in the afterlife". ${ }^{21}$ That is why religious laws prohibit Muslim entrepreneurs from engaging in haram economic and financial activities, such as gambling, usury and speculation. EIP is thus characterised by entrepreneurial, religio-spiritual, socio-economic and ethical values.

\section{EIP as a Means to Social Reform and Societal Well-Being}

Entrepreneurship serves as an engine of economic growth and change. Thus, entrepreneurs must have the ability to act as agents for social, intellectual and ethical-spiritual reform. In our contemporary world, lifestyle reform has come at the hands of innovative and dynamic entrepreneurship undertaken by risktaking individuals. EIP has a lot of potential to promote individual and societal well-being because among Muslims the business development process is not religiously neutral. Businesses as well as consumers, are informed by Islamic epistemology and ethics. This potential and the reservoir of Islamic tazkiya acts as an untapped resource for social reform and societal well-being.

In EIP, there is currently an overemphasis on halal products and services. The expansion of halal businesses means more ethical and social responsibilities for halal business ventures. This halal lifestyle, or what we might call halalised consumption, is the root of the psychological-spiritual-environmental ills of the present day world and, unless EIP pays attention to it, it cannot act as a true 
agent of social-spiritual-ethical reform. ${ }^{22}$ Urban anthropologist Fischer has used concepts such as "halalised piety" and the "ontology of consumption" in his work on Islamic consumption. ${ }^{23} \mathrm{~A}$ halalised lifestyle which does not depict true piety cannot be termed an authentic Islamic lifestyle since it is based on wasteful consumption. Apart from environmental destruction, the physical, psychic and spiritual degradation of consumers is even more detrimental. According to Karim Crow,

Obsessive concern with purist halal food consumption, outer dress or ritualistic observances yields a banal form of Muslim modernity pervaded by shallow materialist consumerism subject to manipulation by state elites for maintaining power and wealth. Humans thus become outwardly more 'Muslim' yet inwardly less Islamic. This paradox lies at the heart of Islamic consumption. Most people everywhere are hungering for the material blessings of the prevailing technoscientific culture, and are content to flatten their inherited faith down to external ritualistic deeds animated by shallow simplified dogmas. Many Muslims now appear to believe more in 'Islam' than in God, and privilege the external trappings of religious identity over a deep personal appropriation of faith and heeding of conscience. This feature of contemporary Muslim identity is frequently commented-upon today: the widespread 'inversion' or reduction of religious understanding and practice to outward symbols and communal observances. This reality offers vendors (whether Muslim, or non-Muslim) a golden opportunity to advance the process of selling Islam, and of profiting from the consumerist mindset of many contemporary Muslims. Once this opportunity is seized, then the way opens to packaging of 'Islam' for consumerist appropriation as a fashion of clothing, as a religiously sanctioned diet, as a personal choice in goods and services which they may purchase or may avoid, as a cluster of images and experiences they may consume and adorn themselves with — in short, as the touted "Halal Lifestyle". ${ }^{24}$

The Islamic categories of daruriyyat (necessities), hajiyyat or takmiliyyat (needs) and tahsiniyyat (luxuries), and the five objectives (maqasid) of shariah are relevant here. ${ }^{25}$ EIP needs to ask which category their product belongs to and caters for, and which it goes against. For instance, Islamic maqasid prescribe that there be no two markets for organic and inorganic businesses in an Islamic community because if organic is healthy for human beings than trading in inorganic, unhealthy food items should become makruh (reprehensible) if not outright haram since it is hazardous for human health and not to be considered 
tayyab (wholesomely pure) for body and spirit. What we eat and how we eat affects our spiritual health too, like the prophetic hadith that mentions how blessings (barakah) can make a lesser amount of food suffice for more. ${ }^{26}$

An example would help illustrate how maqasid ethics could be integrated into EIP. We have the statement of Pietra Rivoli, a professor of economics at Georgetown University that "people like to feel like they are doing something good, and the problem they run into in a country such as the U.S. is that we don't have people who need [clothes] on the scale at which we are producing". Similarly, the nonprofit N Street Village in Washington, D.C., which provides services to homeless and low-income women says that "due to overwhelming support, it can't accept any clothing, with the exception of a few particularly useful and hard-to-come-by items like rain ponchos". Annie Gullingsrud of the Cradle to Cradle Products Innovation Institute, claims that,

Though it's better to downcycle clothes - turn them into less valuable consumer goods like auto-shop rags - than to send them straight to the landfill, it's not a complete solution. Those rags will still find their way to the landfill after a few uses; insulation will be thrown in the dumpster when it's torn out of a wall or old car. Everything is broken down further and further until it eventually reaches the landfill. The cost to the planet isn't just what the stuff does when it's put in the ground, though that's bad enough. The wasted resources it took to create a textile are devastating for the planet. When it ends up in the landfill, it's a wasted material. There's been an expense to the planet. There's been an expense to the company [and] sometimes to the people creating the materials. And it creates a need to use virgin materials. ${ }^{27}$

By offering new cheap clothes, current fashion businesses are asking people to buy more clothes without necessity. But, encouraging Muslims to use second hand clothes could cause the closing down of textile industries. Here the three objectives/maqasid of human life (in terms of health), progeny and wealth (in terms of future environmental resources) conflict with the objective/maqsad of wealth creation (in terms of economic growth, which might suffer with the closing down of industries). Which one to choose? Or could we move to a model whereby the textile industries could switch to work mostly with recycled clothing materials? However, if people only buy according to real/genuine necessity, then even the need for recycled clothing will reduce greatly. The nature of jobs could then change to sustainable cleaning, repairing and tailoring instead of making new clothes.

In the example given above, the religious/spiritual maqsad is also relevant. Many Muslims today fill up their leisure time shopping for unneeded clothes. 
Saving that leisure time for other recreational activities such as spending time with family and neighbours, sports and physical activities, healthy and social cooking activities, community gardening and, most important of all, dhikr (remembrance, worship and contemplation on the meaning and purpose of creation in general and human life in particular) could serve to provide meaning and direction in individual and collective lives. This would help fulfill the religious/social maqsad of maintaining kinship ties and serving the community while also serving the maqsad of preserving life via healthy physical sports and healthy home grown and home-cooked food.

Those who sell a shariah-compliant, halal lifestyle that is at the same time excessive, extravagant and wasteful, operate on the rationale of stimulating the appetitive faculty of the human soul. This innate, appetitive faculty (called shahwah in Islamic normative ethics) is necessary for human survival and even required for the wholesome well-being of a human, both at the individual and communal levels. But the wholesomeness of shahwah is valid only if it has a moderate and balanced constitution, termed itidal in Islamic ethics. I'tidal acts as a normative guide that sifts acquired wants from innate needs and keeps the shahwah in check. The psychic root of human overconsumption is the intense stimulation of this innate, appetitive faculty, which creates immoderate wants and redundant consumption. Persuasion via advanced technological forums tend to replace inner satisfaction and frugal contentment (qana'ah) with outer wants. By conforming to the wants' standard, the individual receives both a physical and emotional reward; physical in terms of fulfilling the want and emotional in terms of social status and appreciation. The halal, spendthrift Muslim culture, although shariah-compliant outwardly, seems to be in conflict with the spirit of Islamic ethics which centres on itidal, qana'ah, and taqwa (mindfulness of God and the afterlife). The contemporary Muslim halal industry, be it of food, fashion and beauty, health products or halal-financed homes and cars, serves to create, induce and intensify human wants, though appearing to be legitimate in terms of shariah legislation. The Islamic values are at best poorly conceived and at worst not given due consideration at all, since Muslims no longer live in a communal universe where these values acted as the "authentic social, moral and civilisational center-of-gravity." ${ }^{28}$ The intensification of desires completely fit in with contemporary postmodern culture, where individual identity has reached the point of idolatry of the self through its projection and aggrandisement, aptly termed idisorder..$^{29}$ According to Crow,

The detailed data accumulated over many decades by advertising agencies concerning the precise cognitive and affective 'push-buttons' for inciting human motivations, for manipulating the commonly 
exemplified types of human delusional self-image, and for inciting lower base impulses are truly impressive. One recalls here classic benchmarks such as flashing 'subliminal images', creative branding, use of semiotics, ego-enhancing appeals to narcissistic emblems, and employing affective 'tags', along with a host of other proven strategies. The wide acceptance today within more 'advanced' affluent contemporary societies of conceptualising 'citizen' status in terms of being a 'consumer' clearly attests to the success of these methods. ${ }^{30}$

The current scholarship on EIP highlights how business obligations and societal welfare intersect in Islam. This has led to religious based innovative products, both financial and technological. Accordingly, the innovative development of "Islamic products and services" must be at the centre of policies aimed to increase Muslim entrepreneurship. However, the Islamic concept of maslaha cherishes, not innovation in itself, but only meaningful innovation that serves a purpose fulfilling one or all of the five objectives in the most comprehensive and coherent manner possible. EIP as an emerging field would require policies that support the integration of this understanding of maslaha as a religious principle in business practices. Miles has further provided the five traits for a Muslim leadership model: Piety, Humility, Social Responsibility, Self-Development, and Mutual Consultation. ${ }^{31}$ According to Faizal et al., the characteristic of entrepreneurs based on the Qur' an and Sunnah are:

1. Taqwa as a framework (Qur'an. 61:10-11). 2. Halal as a top priority (Q. 5:88; Q. 2:168). 3. Do not waste (Q. 7:31). 4. Worship Allah as a priority (Q. 62:10; Q. 15:67). 5. Practicing high moral values (Q. 2:275). 6. Trustworthiness (al-Hadith: al-Tirmidhi. Book 14\#1213; Sahih Bukhari. Vol. 3, Book 41\#576). 7. Concerns for the welfare of others (Q. 22:77; QS. 3:92; Q. 8:3). 8. Knowledgeable (Q. 96:1-5). 9. Caring for society and the environment (Q. 28:77). ${ }^{32}$

We have the following set of traits that qualify as social entrepreneurship. One can see quite clearly how these are already subsumed in the above list.

1. Using innovative solution to solve social problems. 2. Using earned income to solve social problem. 3. Value creation, innovation and opportunity. 4. A change that will solve social problem. 5. Social transformation. 6. Innovation and leadership. 7. Identifying and addressing important social issues in the society. 8. Doing something realistic, affordable, profitable and beneficial to the society. 9. Creating better social values for the society. 10. A social change with a mission to develop people. 11. Innovation by finding a new product, service, or 
something new and different or approach to do things through a socially responsible way. ${ }^{33}$

The problem with non-religious models as against the Islamic religio-ethicalspiritual model is that by not tracing back the psychological-environmental crisis to the spiritual centre, the solution does not reach the root of the problem - that is, the appetitive psyche. For instance, current nutrition education would ask the nutritionists and ordinary folks to only go in the green and dairy section of the supermarket and stay away from the sections of unhealthy processed food. It does not, however, tell them how to restrain the temptation for calorie rich processed food because there is no metaphysical view of nature to inform their paradigm. Hossein Nasr mentions that the tools and methods used to combat contemporary challenges like obesity are the very products of the beliefs and ideas that have brought the upsurge in obesity in the first place. ${ }^{34}$

Islamic knowledge management is another field of enquiry within the EIP to assist Muslims in their role as vicegerents (khalifa). ${ }^{35}$ If Islam is taken as a comprehensive life path that determines an individual's attitude toward themselves (anfus) and the universe (afaq), then the whole culture that carries those beliefs, values and ideals needs to be informed by its parameters. Divine trusteeship turns human beings from physical into cultural and moral beings. Consumerist culture, with its incitement of the lower human self, is one in which businesses only target the material human self. Contemporary social sciences do not include any role for religion in shaping human character. Therefore, businesses are not modeled around the transcendental human self. As Crow (2015) explains:

Times have changed and the heavens ushered in our post-Enlightenment scientific technological era, the age of late-modernity, is ruled by positivist assumptions which essentially give no credence to immaterial reality (the spiritual or transcendent realm), and which privilege material gain above all else. This is an age when the global Halal industry works hand-in-hand with governments to manage the extremely valuable consumer market, and when the potential for profit is so great that spiritual striving and genuine knowledge-practice are easily converted into strictly material gain derived from excitation of appetites.

Some researchers point out the non-materialistic and non-consumerist bent found amongst Muslims. ${ }^{36}$ We again face the question as to why this is not translated into more responsible entrepreneurship when it comes to societal attitude toward overconsumption. This leads us to the idea of whether Muslim entrepreneurs, with their vast repository of intellectual-ethical-religious-spiritual 
knowledge and tradition, become agents of change and reform and fulfill their responsibilities toward humankind. The idea of 'ilm nafi' (beneficial knowledge) in Islamic epistemology is one that includes both thought and practice, knowledge and behaviour. If knowledge creates no observable impact on one's inner self, that knowledge is not serving as a counterpart to the process of inner self-purification (tazkiya).

\section{Conclusion}

Currently Islamic social entrepreneurship has been analysed as a social enterprise with faith-based rules, such as mutual relationship, altruism and goodwill. The key concepts are "unity (tawhid), trusteeship (khilafah) and worship ( ibadah) which will be implemented for social justice and public interest". ${ }^{37}$ Islam describes the human being as the khalifa (vicegerent) on earth. This Qur'anic term denotes the comprehensive and functional character of a human being whose knowledge and understanding of God and the purpose of life informs his/her personality and conduct, both individual and collective. A Muslim entrepreneur must abide by the dictates of justice and should not deliberately be the cause of any harm to society, whether explicit or tacit. Doing business in this way becomes one of the greatest acts of worship ('ibadah). Having a useful and ethical business that fits in with the philosophy of tawhid (oneness of God) elevates the rank of a Muslim entrepreneur.

To come up with a more relevant model for Muslim entrepreneurship, the ideas of social change and reform, inherent in social entrepreneurship, need to be seen in the light of concepts such as qana'ah (frugal contentment), rida (temperate satisfaction) and zuhd (renunciation of appetitive wants). These intellectual-spiritual-moral practices found in the Islamic sources could lead to both individual and social benefits. The contemporary entrepreneurship model turns human beings into consumers and places the gratification of desires over and above the ethical-spiritual practice of inner self-sufficiency and moderating contentment. Muslim entrepreneurs need to develop and inspire simpler lifestyles and sustainable consumption patterns amongst their community members and the world at large. Despite crass commercialism and mass culture steering our lives, the ideals of qana'ah and rida are deeply entrenched as the highest values and virtues in Islamic socio-economic ethics, both on the individual and communal levels. This makes it possible to invoke them as guiding principles for entrepreneurs. The Prophetic hadith, "Verily, I have only been sent to perfect righteous character (akhlaq)", ${ }^{38}$ sums up the ideal of business ethics from an Islamic perspective in this regard. 
In direct opposition to the Qur'anic imperative to not cause corruption on earth (fasad fi al-ard) $(28: 77 ; 30: 41)$, we know how the earth and human lives have been damaged due to individuals caught in the trap of endless consumption. Corporations often reap profits from this psycho-spiritual and ecological degradation. It is a corporate-directed wasteful consumption that is entirely opposed to the Qur'anic injunction (25:67) against spending extravagantly or niggardly and to pursue an upright and moderate life. Muslim entrepreneurs should assume the responsibility of infusing Shariah-compliant businesses with the true Islamic spirit, to create authentic happiness for Muslims in their identity as 'abd (slaves) and not as consumers. The current corporate model provides instant gratification of both physical and psychic appetites, creating a narcissistic culture. Muslim entrepreneurs through their social-spiritual vision, need to reinforce the Islamic virtues of contentment, balanced moderation with frugal restraint, compassion, generosity, and avoidance of wastefulness and extravagance.

\section{Notes}

* Amana Raquib is an assistant professor at the Institute of Business Administration Karachi, Pakistan.

** Imran Khan is an assistant professor at the Institute of Business Administration Karachi, Pakistan.

Amana Raquib would like to thank CEIF, IBA, who generously granted her conference funding to present this paper at LUMS, and also to Dr. Junaid Qadir (ITU, Lahore) who offered useful critiques which helped improve this paper.

1. http://www.tandfonline.com/doi/full/10.1080/14766080903290143?scroll=top \&needAccess $=$ true.

2. See the following works: Abul Hassan, 'Islamic ethical responsibilities for business and sustainable development,' Humanomics 32, no. 1 (2016): 80-94. Necati Aydin, 'Islamic social business for sustainable development and subjective wellbeing,' International Journal of Islamic and Middle Eastern Finance and Management 8, no. 4 (2015): 491-507; Faried Kurnia Rahman, Mohammad Ali Tareq, Rochania Ayu Yunanda, and Akbariah Mahdzir, 'Maqashid Al-Shari'ahbased Performance Measurement for the Halal Industry,' Humanomics 33, no. 3 (2017): 357-370; Niaz Ahmed Khan, 'Sustainable Development and Islamic Ethics: A Primer on the Conceptual Linkages,' in $21^{\text {st }}$ Century Challenges for the Global Muslim Community: Knowledge, Development and Revival: Selected Oriental Perspectives, ed. A. Farid and N.A. Khan (Dhaka: RFHRM, 2008), 137-50. 
3. One notable exception is the Uboodiyah Business Model. Available at: www. ubmtrust.org. (Accessed on: 28 September 2018).

4. Mark Anielski, The Economics of Happiness (Gabriola Island: New Society Publishers, 2007).

5. Ibid., 21.

6. Ibid., 33-49.

7. See: Seyyed Hossein Nasr, Islam and The Plight of Modern Man (Cambridge: The Islamic Texts Society, 2002); Adi Setia, 'Freeing Maqasid and Maslaha from Surreptitious Utilitarianism,' Islamic Sciences 14, no. 2 (2016):127-57; Amana Raquib, Islamic Ethics of Technology: An Objectives 'Approach (Petaling Jaya: The Other Press, 2015).

8. Junaid Qadir and Asad Zaman, 'Sustainable Development Viewed from the Lens of Islam,' Int. Journal of Pluralism and Economics Education (forthcoming).

9. The following are a few examples of the steps being taken all across the world to encourage sustainable consumption. Not a single Muslim entrepreneur is seen to be taking any such initiatives.

http://www.newsweek.com/2016/09/09/old-clothes-fashion-wastecrisis-494824.html;

http://www.waste360.com/Recycling_And_Processing/shoe-recycling-201004; https://www.huffingtonpost.com/entry/your-kids-toys-are-killing-the-planet us_58ffa383e4b0f5463a1a9472;

http://www.greentoys.com/our-passion\#4?show=content;

https://www.bigfuturetoys.com/;

https://www.theguardian.com/sustainable-business/sustainable-fashionblog/2015/feb/26/waste-recycling-textiles-fashion-industry;

http://www.thegoodtrade.com/features/15-ethical-shoe-brands-for-everyoccasion;

https://ecocult.com/the-18-most-affordable-places-to-buy-ethical-fashion

10. V. Ramadani et al., ed. Entrepreneurship and Management in Islamic Context (Springer Islamabad Publishing, 2017), 15.

11. http://www.newsweek.com/2016/09/09/old-clothes-fashion-wastecrisis-494824.html

12. http://www.newsweek.com/2016/09/09/old-clothes-fashion-wastecrisis-494824.html

13. "The holy grail for sustainability in fashion is closed-loop sourcing"...Closedloop technology, where a product is recycled back into almost the same product, is a tantalising prospect for sustainability advocates, because it essentially mimics the natural process of life..."The used-clothing industry is going through an extremely difficult period both here in the U.K. and globally," Alan Wheeler, director of the Textile Recycling Association in the U.K., told Sourcing Journal in April. "Yet consumption of new clothing is continuing to rise, with clothing prices still generally much lower than they used to be... If clothing quality continues to fall, demand from the international market drops even further and the closed-loop recycling technology doesn't come through, we might have a secondhand clothing crisis. And then there wouldn't be any place at all to take your cheap, old clothes". Available at: http://www.newsweek.com/2016/09/09/ old-clothes-fashion-waste-crisis-494824.html 
14. https://www.khazanay.pk/

15. Daud Batchelor, 'Reducing Wasteful Consumption Towards Sustainability by Waste Avoidance Using Self-Improvement (Tazkiya) and Contentment (Qana'ah) Approaches' in Islamic Perspectives on Science and Technology: Selected Conference Papers ed. Mohammad Hashim Kamali et al (Singapore: Springer, 2016), 193-212.

16. Nazamul Hoque, Abdullahi Mamun and A.M.A. Mamun, 'Dynamic Traits of Entrepreneurship: An Islamic approach,' World Journal of Entrepreneurship, Management and Sustainable Development 10, no. 2 (2014): 128-42.

17. Ramadani et al.

18. https:/www.theguardian.com/technology/2017/oct/05/smartphone-addictionsilicon-valley dystopia

19. A.J.M.N. Chowdhury, 'Towards an Islamic Model of Entrepreneurship,' in Management: Islamic Perspective, ed. M. Loqman (Dhaka: BIIT, 2008), 6-19.

20. Raquib 2015.

21. Ramadani et al., 2.

22. There are some notable exceptions such as the following:

Muatasim Ismaeel, Katharina Blaim, 'Toward Applied Islamic Business Ethics: Responsible Halal Business', Journal of Management Development 31, no. 10 (2012):1090-100.

23. Johan Fischer, Proper Islamic Consumption: Shopping among the Malays in Modern Malaysia (Copenhagen: NIAS Press, 2008).

24. Karim D. Crow, 'Consuming Islam: Branding 'Wholesome' as Lifestyle Fetish,' Islamic Sciences 13, no. 1 (2015): 3-26.

25. Raquib, 2015.

26. Allah's Messenger said, "The food for two persons is sufficient for three, and the food of three persons is sufficient for four persons." (Sahih Bukhari 5392, Book 70, Hadith 20).

27. http://www.newsweek.com/2016/09/09/old-clothes-fashion-wastecrisis-494824.html

28. Crow, 2015.

29. Larry D. Rosen, IDisorder: Understanding Our Obsession with Technology and Overcoming Its Hold on Us (New York: Palgrave Macmillan, 2012).

30. Crow, 2015.

31. Miles. K. Davis, and John Winn, 'Islamic Leadership Models: Lessons from Early Islam' in Entrepreneurship and Management in an Islamic Context, ed. V. Ramadani et al (London: Springer, 2017), 19-32.

32. P. R.M. Faizal, A. A. Ridhwan and A. W. Kalsom, 'The Entrepreneurs' Characteristic from al-Qur'an and al-Hadis,' International Journal of Trade, Economics and Finance 4, no. 4 (2013): 191-6.

33. Ramadani et al., 146.

34. Nasr, 2002.

35. Ramadani et al., 106.

36. Vanessa Ratten et al, 'Islamic Entrepreneurship and Management: Culture, Religion and Society' in Entrepreneurship and Management in Islamic Context, ed. V. Ramadani et al (Switzerland: Springer International Publishing, 2017), $227-42$. 
ENTREPRENEURSHIP AS AN AGENT FOR SOCIAL-ETHICAL REFORM: AN ISLAMIC PERSPECTIVE

37. Ramadani et al., 152.

38. Muwatta 1614, Musnad Ahmad 8595. 